Article

\title{
Between Environmental Utilization and Protection: Adolescent Conceptions of Biodiversity
}

\author{
Jennifer Schneiderhan-Opel *(i) and Franz X. Bogner ${ }^{(\mathbb{O}}$ \\ Centre of Math \& Science Education (Z-MNU), Department of Biology Education, University of Bayreuth, \\ NW1, 95447 Bayreuth, Germany \\ * Correspondence: jennifer.schneiderhan@uni-bayreuth.de
}

Received: 5 July 2019; Accepted: 18 August 2019; Published: 21 August 2019

\begin{abstract}
As human activities threaten biodiversity on a global scale, preventing further biodiversity loss requires scientifically literate and environmentally responsible citizens. Biodiversity education (BE) as part of education for sustainable development (ESD) may lay the foundation of fostering a sense of responsibility for biodiversity and its preservation among future generations. Meaningful learning depends on the integration of new knowledge into already existing student conceptions (i.e., students' pre-instructional mental concepts and ideas of teaching subjects). Thus, assessment and consideration of student conceptions on biodiversity are of high relevance for the development of successful BE and ESD lessons. In the present qualitative study, we applied three open-ended questions in a paper-and-pencil format to assess adolescents' pre-instructional conceptions on biodiversity, its benefits, and protection. Almost our total sample of 275 German 10th graders equated biodiversity with species diversity, revealing an only fragmented understanding of the scientific concept of biodiversity. Conceptions of the benefits of biodiversity were almost equally balanced between environmental and economic benefits. Notions of environmental preservation considerably outnumbered notions of environmental utilization in student conceptions of biodiversity protection.
\end{abstract}

Keywords: conceptions; biodiversity education; education for sustainable development; biodiversity education; environmental preservation; environmental utilization

\section{Introduction}

Following the definition of the Millennium Ecosystem Assessment (MA), biodiversity is regarded as "the variability among living organisms from all sources including, inter alia, terrestrial, marine and other aquatic ecosystems and the ecological complexes of which they are part; this includes diversity within species, between species and of ecosystems" [1] (p. 18). What is important to this definition is that the concept of biodiversity covers three dimensions: ecosystem diversity, species diversity, and genetic diversity and should not—as it is often the case-be equated to species diversity only. It has been 16 years since the Convention on Biological Diversity (CBD) was opened for signature at the Rio de Janeiro Earth Summit, in June 1992 [2]. Altogether 196 countries agreed upon the common goal to reduce biodiversity loss and to achieve biodiversity conservation as well as its sustainable development by 2010 [3].

Since the goal had not been reached, CBD parties set up the Strategic Plan for Biodiversity and the Aichi Biodiversity Targets, to be met until $2020[4,5]$. To date, biodiversity change and loss is still a major global challenge [6]. Recent studies, e.g., on the decline of flying insect species, indicate no positive change [7]. The bioethical value of biodiversity may be seen from an ecocentric or anthropocentric point of view [8]. Both represent positive perspectives towards nature preservation but differ in its justification. Following the definition by Washington et al. we use the term ecocentrism as an umbrella term for a nature-centered value system that includes biocentric and zoocentric worldviews [9]. 
In contrast to ecocentrism, anthropocentrism is a human-centered value system that is focused on nature's value for human well-being only and places the human species above all other organisms $[8,10]$. Concerning the intrinsic value of nature, "biodiversity is now known to be a major determinant, perhaps the major determinant, of community and ecosystem dynamics and functioning" [11] (p. 472). As biodiversity determines ecosystem functioning, there is also a strong link between biodiversity and ecosystem services [12]. Ecosystem services are goods and benefits that are provided to humans by ecosystems and are directly linked to human well-being [1,12]. Following the MA, these services can be categorized into provisioning services (e.g., food or freshwater), regulating services (e.g., climate regulation), cultural services (e.g., aesthetic or spiritual values) and supporting services (e.g., primary production) [13]. The latter form the basis of all the other ecosystem services. Hence, biodiversity is one of the key elements of environmental functioning and is essential to human well-being. Paradoxically, however, biodiversity change and loss are mainly caused by human activity [14]. The large impact humans have on biodiversity or vice versa implies that any attempt to address biodiversity protection strongly relies on an environmentally literate and aware society.

Today's school students will be the political decision-makers of the future. What is more, current international climate movements once again emphasize that young people's potential influence and leverage in state and society should not be underestimated. Thus, formal science education must deal with socio-scientific issues to support students in becoming responsible citizens who can actively take part in societal decision-making processes concerning scientific-related matters [15]. Following the definition by [16] (p. 1), we consider biodiversity a socio-scientific issue, as it "has a basis in science and has a potentially large impact on society". We recognize biodiversity education therefore as a highly important section of formal education for sustainable development (ESD), with the specific aim of fostering learners' sense of responsibility to protect biodiversity and promote suitable problem-solving skills.

The importance of biodiversity education has also been recognized by the CBD. Education is anchored in Article 13, as well as in the Aichi Biodiversity Target 1, that says, "[b]y 2020, at the latest, people are aware of the values of biodiversity and the steps they can take to conserve and use it sustainably" [5] (p. 1). The strategy for its implementation is covered by the CBD's Communication, Education and Public Awareness (CEPA) program, which is aimed at, among other things, incorporating the topic of biodiversity into the education of all member states.

One important prerequisite for the development of successful ESD approaches and lessons is the involvement of student conceptions and ideas on the content to be taught. Students do not attend science classes as blank slates. Instead, they come to lessons having in mind certain conceptions of the respective scientific topic, mainly originating from personal experiences [17]. These 'pre-instructional conceptions' [18] are not always consistent with correct science views and concepts. Literature provides many different terms for such student conceptions, which are not or only partly scientifically accurate. Frequently used expressions are 'misconceptions' [19], 'alternative conceptions' [20] or 'naïve conceptions' [21]. Within our paper, we will use the neutral term 'alternative conceptions' in order to avoid judgment of student ideas.

Monitoring learners' conceptions has a long history, starting in the 1970s, building on constructivism theories, particularly on Piaget's theory of cognitive development [22,23]. The assumption that the construction of new knowledge relies upon the modification and re-arrangement of pre-existing cognitive schemes forms the basis of the constructivist view of learning [24]. Consequently, students' alternative conceptions represent productive prior understandings, which are used by students 'as resources for building more sophisticated scientific understandings' [22] (p. 353). Playing a key role in learning processes, identifying common alternative conceptions is therefore of considerable interest for both science researchers and science educators. Concerning the topic of biodiversity and its preservation, we suggest that knowledge of student conceptions of biodiversity determines fruitful biodiversity education and consequently affects the success to foster responsible citizenship. Among others, Lindemann-Matthies and Bose [25] described knowledge as an important determinant for 
developing appreciative attitudes towards biodiversity. Therefore, our study focused both on students' familiarity with the term biodiversity as well as on their awareness of biodiversity. Do they appreciate the benefits of biodiversity and consider biodiversity protection as important? There are several studies concerning the awareness of biodiversity among the general public, e.g., [26-29]. Despite their significance for formal science learning, there is a rather limited scope of studies concerned with adolescent conceptions of biodiversity, e.g., [25,30,31]. Our present large-scale study, therefore, followed three research questions:

1. Which conceptions of biodiversity can be identified among German adolescents?

2. Which benefits of biodiversity do they recognize?

3. Which conceptions of biodiversity protection can be identified?

\section{Materials and Methods}

Our convenience sample consisted of 275 10th graders from different secondary schools in Bavaria, Germany. All schools are located in more rural areas rather than in large cities. Data was collected in a pre-study prior to students' participation in an environmental learning module. Teachers enrolled their classes for participation in the module and the accompanying study and parents had to sign an informed consent. The students' mean age was $15.27(\mathrm{SD}=0.66)$. Gender distribution was roughly even ( $46.49 \%$ were female). Students completed a paper-pencil survey with three open-ended questions (Table 1) during regular school lessons. Predefined lines suggested the expected scope of the answers.

Table 1. Survey questions.

\begin{tabular}{cc}
\hline Question & Wording \\
\hline question 1 & What do you understand by the term biodiversity (=biological diversity)? \\
question 2 & What are the benefits of biodiversity? Give reasons for your answer. \\
question 3 & Should biodiversity be protected? Give reasons for your answer. \\
\hline
\end{tabular}

Student answers were analyzed following the qualitative content analysis by Mayring [32]. We inductively built different categories based on the most frequent student answers. It has to be noticed that multiple category assignments were possible, i.e., a student answer could consist of more than one conception. Therefore, the numbers and percentages presented in our paper represent conceptions not the number of answers or students. To demarcate the categories as precisely as possible, our coding guidelines included a clear definition of every category and an anchor example for each category, which we regarded as representing the category best. Table 2 displays an excerpt of our coding guidelines.

Table 2. Excerpt of the coding guidelines using the example of categories for question 1.

\begin{tabular}{cll}
\hline Category & \multicolumn{1}{c}{ Definition } & \multicolumn{1}{c}{ Anchor Example } \\
\hline species diversity & $\begin{array}{l}\text { the biological species concept is } \\
\text { explicitly expressed }\end{array}$ & $\begin{array}{l}\text { "Many different species of plants } \\
\text { and animals." }\end{array}$ \\
\hline variety of creatures & $\begin{array}{l}\text { the variety of living creatures is expressed } \\
\text { without mentioning the biological species concept }\end{array}$ & $\begin{array}{l}\text { "The variety of living organisms } \\
\text { on earth." }\end{array}$ \\
\hline $\begin{array}{c}\text { disparity of } \\
\text { creatures }\end{array}$ & $\begin{array}{l}\text { the statement focuses on the differences between } \\
\text { living beings }\end{array}$ & $\begin{array}{l}\text { "I think that all kinds of plants and } \\
\text { animals are different." }\end{array}$ \\
\hline genetic diversity & the diversity within species is explicitly expressed & "The genetic diversity within a species." \\
\hline ecosystem diversity & the diversity of ecosystems is explicitly expressed & "Different ecosystems." \\
\hline $\begin{array}{c}\text { scientifically correct } \\
\text { concept }\end{array}$ & all three dimensions of biodiversity are expressed & $\begin{array}{l}\text { "Biodiversity is the diversity of genetic } \\
\text { information, species and ecosystems." }\end{array}$ \\
\hline
\end{tabular}


To validate our categories, we confirmed an intra- and inter-rater reliability test and determined the Cohen's kappa values of agreement between the raters (Table 3) [33]. For this purpose, we randomly selected $15 \%$ of all student answers for each question. After three months, the first author categorized this dataset for a second time (intra-rater) and a nonpartisan person did the inter-rating. The resulting Cohen's kappa scores in the range of 81-1.00 indicate an 'almost perfect' agreement between the raters [34].

Table 3. Cohen's kappa scores for inter- and intra-rater reliability.

\begin{tabular}{lcc}
\hline & \multicolumn{2}{c}{ Cohen's Kappa Score } \\
\hline Question & Intra-Rater Reliability & Inter-Rater Reliability \\
\hline question 1-categorization a & 0.97 & 0.89 \\
question 1-categorization b & 0.95 & 1 \\
\hline question 2 & 0.95 & 0.87 \\
\hline question 2-justification & 0.95 & 0.98 \\
question 3-justification & 0.98 & 0.98 \\
\hline
\end{tabular}

In the following, we outline the results of the categorization of the student answers. Responses falling into the category 'expression of ignorance' as well as 'inadequate answer' are counted as 'no answer'. Single conceptions did not form a category and were summarized in 'other'. For better clarity, the categories 'no answer' and 'other' are not displayed in the Figures. Unless otherwise stated, frequencies represented are related to the total number of conceptions for each question or subquestion $\left(\mathrm{n}_{\text {conceptions }}=100 \%\right)$.

\section{Results}

\subsection{Question 1: What Do You Understand by the Term Biodiversity?}

Question 1, 'What do you understand by the term 'biodiversity' (=biological diversity)?' generated 306 conceptions fitting into four categories 'one dimension' (46\%), 'two dimensions' ( $2 \%)$, 'three dimensions' (1\%), 'no dimension' (27\%) (see Figure 1). We further subcategorized the conceptions relating to 'one dimension' $\left(\mathrm{n}_{\text {sub }}=125\right)$ into the three dimensions of biodiversity 'species diversity' $(97 \%)$, 'genetic diversity' (2\%) and 'ecosystem diversity' (1\%). Table 4 provides examples of student answers and illustrates the assignment of individual conceptions to the categories.

Table 4. Categorization of students' conceptions on the term biodiversity.

\begin{tabular}{|c|c|c|c|c|}
\hline \multirow{2}{*}{ Category } & \multicolumn{3}{|c|}{ Dimension of Biodiversity } & \multirow{2}{*}{ Student Example Quote } \\
\hline & $\begin{array}{c}\text { Species } \\
\text { Diversity }\end{array}$ & $\begin{array}{c}\text { Genetic } \\
\text { Diversity }\end{array}$ & $\begin{array}{c}\text { Ecosystem } \\
\text { Diversity }\end{array}$ & \\
\hline one dimension & + & & & $\begin{array}{l}\text { ID 12: 'It is the diversity of } \\
\text { species, for example, animal or } \\
\text { plant species.' }\end{array}$ \\
\hline two dimension & + & & + & $\begin{array}{l}\text { ID 83: 'The different animal } \\
\text { and plant species [ ... ]. But } \\
\text { also the different habitats.' }\end{array}$ \\
\hline all dimensions & + & + & + & $\begin{array}{l}\text { ID 35: 'Biodiversity is the } \\
\text { diversity of genetic information, } \\
\text { species and ecosystems.' }\end{array}$ \\
\hline $\begin{array}{l}\text { none of the } \\
\text { dimensions }\end{array}$ & & & & $\begin{array}{l}\text { ID 118: 'That there are many } \\
\text { biological molecules.' }\end{array}$ \\
\hline
\end{tabular}




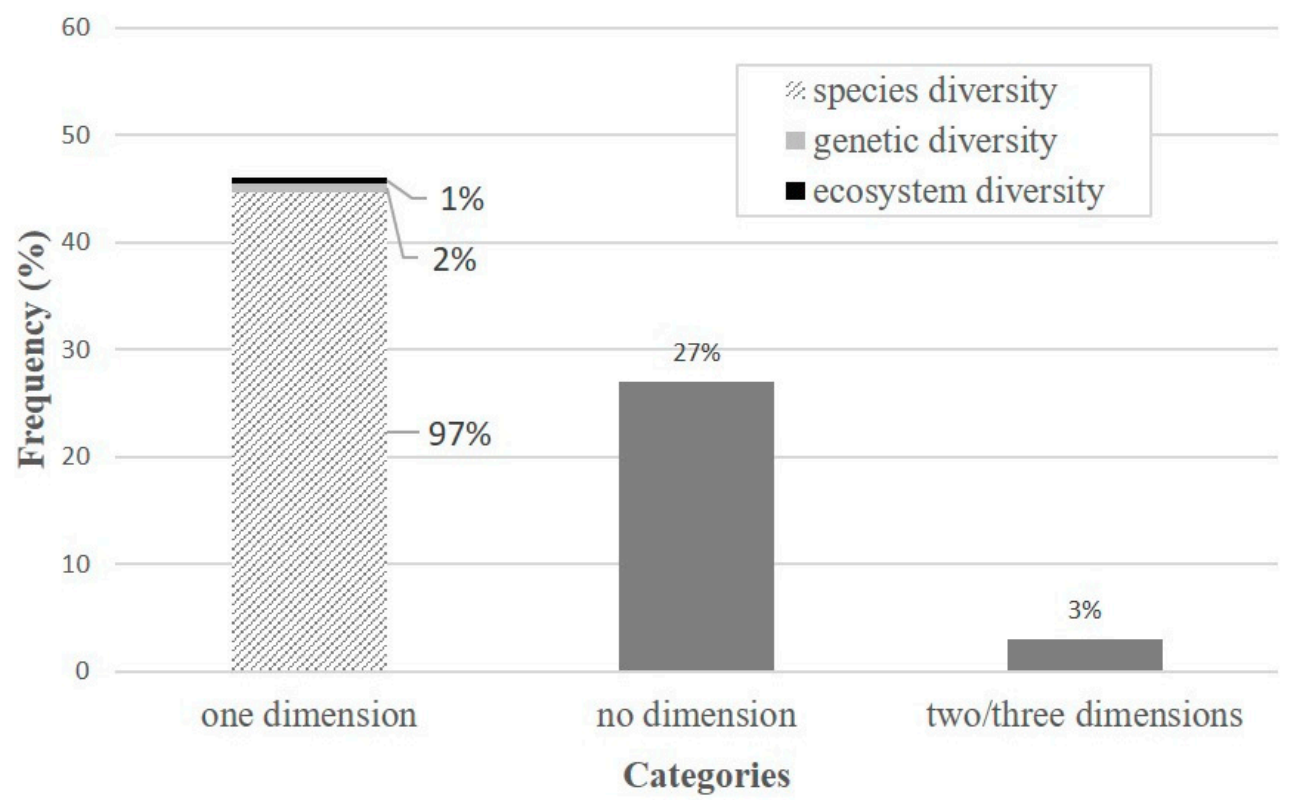

Figure 1. Frequencies of student conceptions referring to the concept of biodiversity (question 1; categorization a. Frequencies on the $\mathrm{y}$-axis are related to the sum of all student conceptions $\left(\mathrm{n}_{\text {conceptions }}\right.$ =306). Frequencies displayed for the category 'one dimension' are related to the number of conceptions concerning one dimension of biodiversity $\left(n_{\text {sub }}=125\right)$. For reasons of simplicity, the categories 'two dimensions' and 'three dimensions' are summarized.

For a further illustration of the student conceptions concerning the concept of biodiversity $\left(\mathrm{n}_{\text {conceptions }}=306\right)$, we categorized them again into the six inductive categories 'species diversity' $(41 \%)$, 'variety of creatures' (19\%), 'disparity of creatures' (8\%), 'genetic diversity' (2\%), 'ecosystem diversity' (2\%) and 'scientifically correct conception' (1\%) (Figure 2 ).

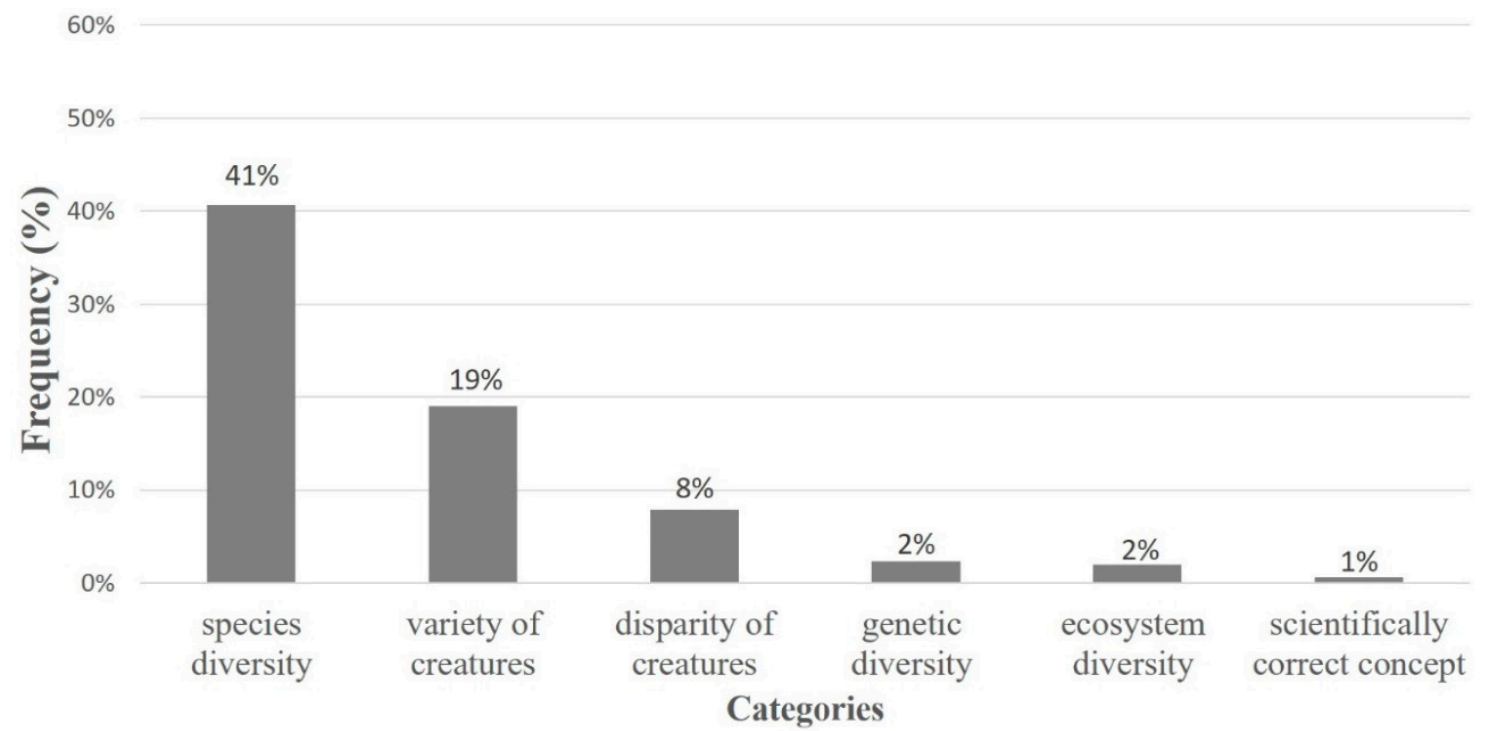

Figure 2. Frequencies of student conceptions included in answers to question 1; categorization $b$. $\mathrm{n}_{\text {conceptions }}=306$.

In our coding guidelines, we determined that only conceptions actually containing the biological species concept are categorized as 'species diversity', otherwise conceptions were coded as 'variety of creatures'. For example, the student example quote (student ID 220), 'That there are many animal and plant species' contained one statement, which was categorized as 'species diversity', whereas the 
student answer (student ID 215), 'This is the variety of biological creatures. This includes animals, plants, organisms etc.' fell into the category 'variety of creatures' because the included statement did not contain the biological species concept but did refer to the great variety of living organisms. In contrast, statements of the category 'disparity of creatures' explicitly referred to different characteristics or appearances of living beings. For example, the answer (student ID 250), 'This is the diversity of species, which all have different characteristics' fell into the category 'species diversity' and 'disparity of creatures'.

\subsection{Question 2: What Are the Benefits of Biodiversity?}

The first part of question 2 'What are the benefits of biodiversity?' generated 185 answers and 240 conceptions ( $n_{\text {answers }}=185 ; n_{\text {conceptions }}=240$ ) (Figure 3). Most conceptions fell into the category 'humans' (52\%), followed by 'animals and plants' (34\%) and 'every living thing' (21\%). Answers related to the category 'every living thing' contained conceptions about living creatures with no further specification. For example, the student answer (student ID 72), '[f]or all living things, because biodiversity is important for the food chain for example' fell into this category because the student did not specify what is referred to as 'living things'. This statement could include humans as well as animals, plants, etc, and we therefore coded it as 'every living thing'. Least conceptions (17\%) were associated with the category 'inanimate nature'.

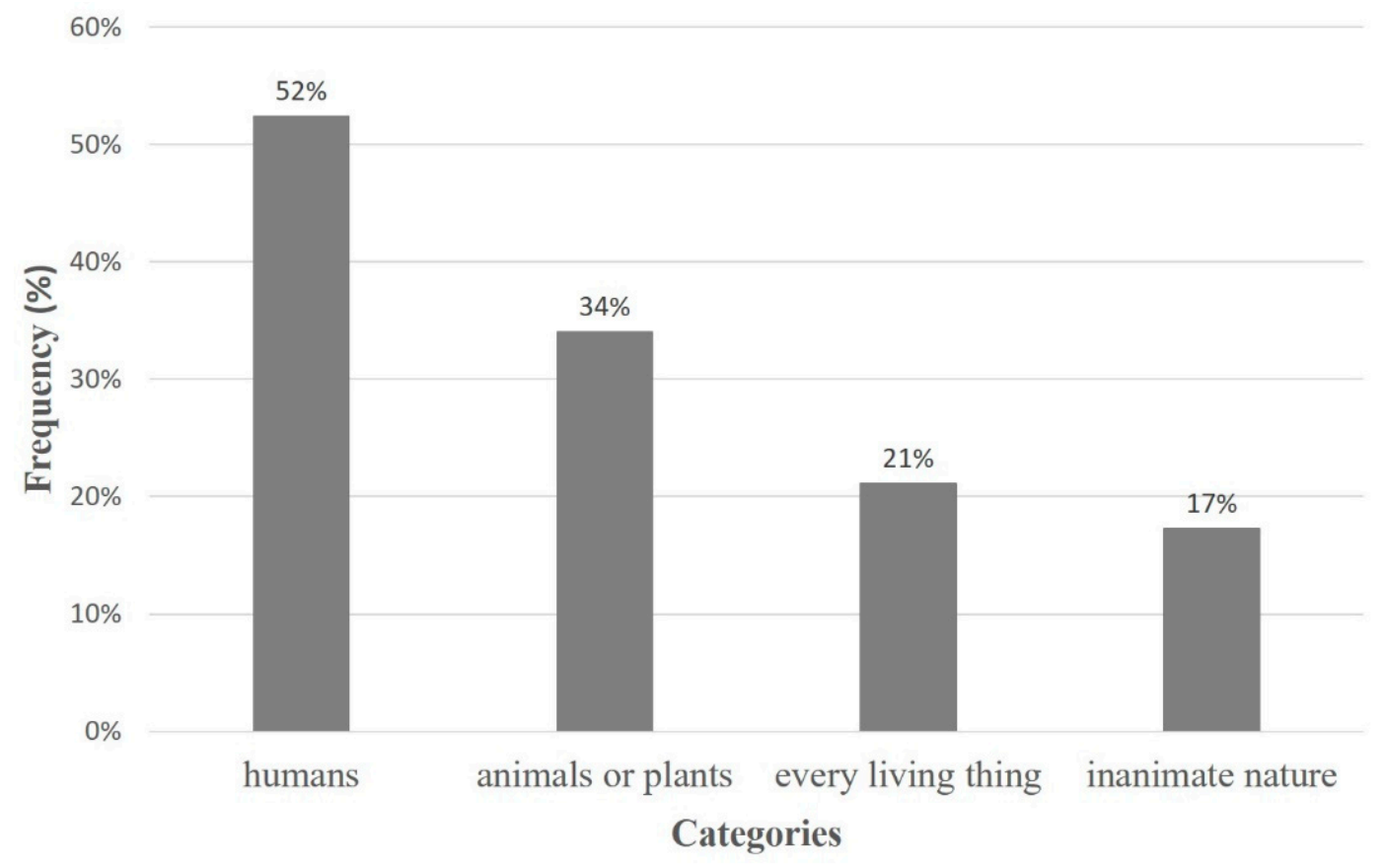

Figure 3. Frequencies of student conceptions to question 2. $\mathrm{n}_{\text {conceptions }}=240$.

We categorized the reasons for question 2 separately (Figure 4). Of a total of 185 answers, $67 \%$ were justified $\left(n_{\text {justification }}=124\right)$ and generated 154 conceptions $\left(n_{\text {conceptions }}=154\right)$. Most of the justifying conceptions were associated with the category 'ecosystem services' (43\%). These were further subcategorized as 'research and medicine' (36\%), 'food products' $(32 \%)$, 'photosynthesis and air purification' (11\%), 'natural resources' (11\%) and 'other' (11\%). For example, one student answer (student ID 22) was, '[biodiversity] is advantageous for every viable organism: if there was no biodiversity but only humans (not possible) $\rightarrow$ What would [humankind] live on? Where would the oxygen come from? [ ... ] On what would [humankind] write on (paper)?'. This answer contained three conceptions, which fell into the categories 'food products', 'photosynthesis and air purification' and 'natural resources'. 


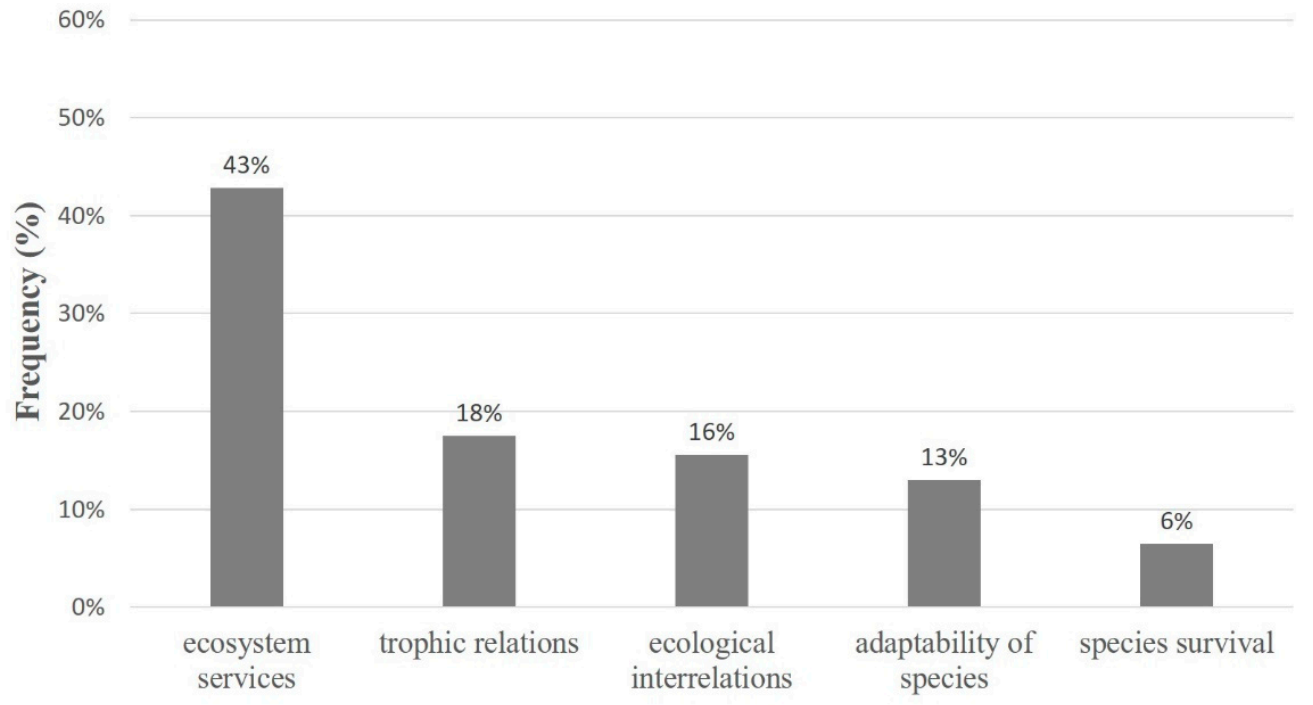

Categories

Figure 4. Frequencies of student conceptions on the benefits of biodiversity (question 2). $\mathrm{n}_{\text {conceptions }}=154$.

The remaining conceptions were not related to humans and generated the categories 'trophic relations' $(18 \%)$, 'ecological interrelations' $(16 \%)$, 'adaptability of species' $(13 \%)$, 'species survival' $(6 \%)$ and 'other' (4\%). For example, the student statement (student ID 23), '[f]or bees, because they need the variety of plants' was coded as 'ecological interrelations'.

\subsection{Question 3: Should Biodiversity Be Protected?}

Question 3 was answered by $77 \%$ of the students $\left(n_{\text {answers }}=210\right)$. Of these students, $98 \%$ said 'yes' but only $60 \%$ of them $\left(n_{\text {justification }}=145\right)$ gave reasons to justify their answer. We separated the justifying conceptions $\left(\mathrm{n}_{\text {conceptions }}=159\right)$ into two categories 'environmental utilization' $(30 \%)$ representing notions concerned with the value of biodiversity for humans and 'environmental preservation' $(70 \%)$, representing notions concerned with the value of biodiversity for animate and inanimate nature (Figure 5).

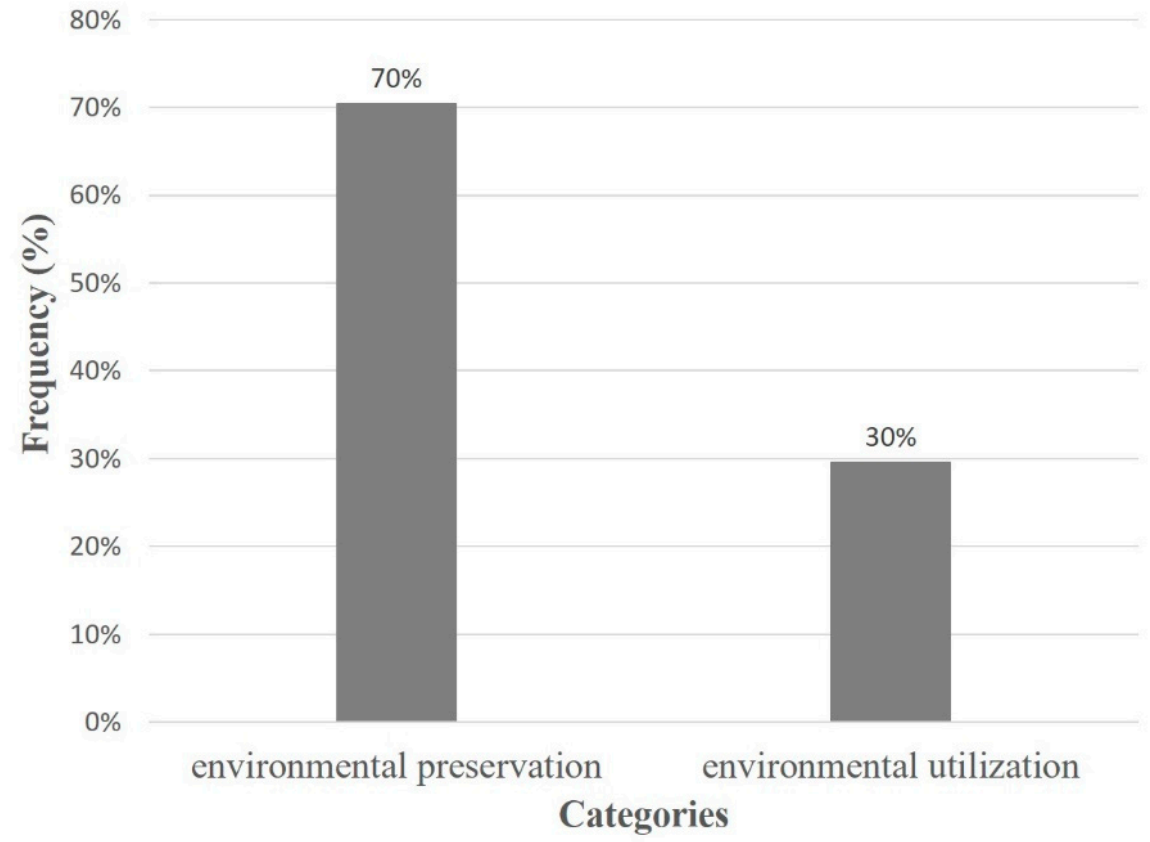

Figure 5. Frequencies of student conceptions justifying the protection of biodiversity. $\mathrm{n}_{\text {conceptions }}=192$. 
We further subcategorized the conceptions concerning 'environmental utilization' into the subcategories 'ecosystem services' (91\%) and 'research' (9\%). The category 'environmental preservation' is composed of the six subcategories 'preventing species extinction' $(52 \%)$, 'species interactions' $(28 \%)$, 'adaptability of species' ( $8 \%)$, 'respect for nature' (7\%) and 'development and evolution' (5\%). For example, the student statement (student ID 31), ' [ ... ] no species should die out, for example just because we clear rainforests', is classified as 'preventing species extinction'. An important result is that only 7 out of 162 student answers justified biodiversity by expressing equally notions of environmental preservation and utilization. The rest of the student answers contained conceptions solely ascribed to one of the main categories.

\section{Discussion}

Existing research on conceptions of biodiversity primarily focuses on biodiversity awareness of the public, university students or teachers with adults as the main target group $[26,28,35,36]$. Despite their significance for biodiversity education, only a small body of research is concerned with adolescent's conceptions of biodiversity. The present large-scale study, therefore, monitored conceptions of German secondary school students concerning biodiversity, its benefits, and protection.

\subsection{Biodiversity is Equated with Species Diversity}

Our first objective was to capture student ideas on the term 'biodiversity'. Since our written questionnaire design did not allow individual follow-up questions, our question contained both the German term for 'biodiversity' ('Biodiversität') and its synonym 'biological diversity' ('biologische Vielfalt'), to prevent mere word comprehension problems. Our findings coincide with our expectations and the existing literature, e.g., [26,30,31]. Most students equated biodiversity with species diversity, neglecting the dimensions of ecosystem diversity and genetic diversity. Three students at least referred to genetic diversity indirectly. For example, one student (ID 16) wrote, 'There are many different organisms within one species. None is just like the other. Each [individual] differs in at least one feature from the others of its species.' Here, the student relates to the variety within species, i.e., genetic diversity, but does not explicitly express it.

Nevertheless, two dimensions of biodiversity, crucial for the understanding of the overall concept, are not present in the vast majority of student conceptions. What might be the reasons for this fragmented understanding? We suggest that possible sources are media and teachers. Previous research on student conceptions has shown that media is an important source of information for students and may increase the risk of the formation of alternative conceptions [37,38]. Lindemann-Matthies and Bose [25] examined public familiarity with the term biodiversity and found that most participants came across the term 'biodiversity' via media. Especially in Germany, the term 'Artenvielfalt', which literally means 'species diversity', is still more commonly used outside the scientific community than the term 'Biodiversität', which better characterizes the concept 'biodiversity'. For example, the term 'Artenvielfalt' was used in the German versions of the Eurobarometer surveys of the European Commission until 2015 [28].

In addition, there are several studies arguing that teachers hold alternative conceptions themselves [39], which they quite likely pass on to their students. Our suggestion is consistent with Fiebelkorn and Menzel [40], who examined preservice biology teachers' conceptions of biodiversity. Qualitative interviews revealed that the participants reduced biodiversity to species diversity and held alternative conceptions of genetic diversity.

\subsection{Recognition of the Benefits of Biodiversity}

Students named animate and inanimate nature as wells as humans as beneficiaries of biodiversity with a slight majority on expressions about the environment.

Almost all answers on humans as beneficiaries contained ecosystem services, for example, provisioning of timber, medicine or food products. It should be noticed here that no student actually 
used the term 'ecosystem service'. We therefore suggest that the students are not familiar with the concept as such, but they are still aware of several goods and services provided by ecosystems.

The subcategories of 'ecosystem services' were mainly provisioning and regulating services. Remarkably few student conceptions included supporting and cultural services. For example, one student addressed the aesthetic value of biodiversity by writing, 'If everything was equal, the 'aspects of beauty' of the environment would be missing and it would be boring'. Here the student directly refers to the aesthetic value of the natural environment and concludes that diversity is more valuable than equality or monotony. We think that the majority of students are either not aware of supporting or cultural ecosystem services or they prioritize provisioning and regulating services over the other two. The latter suggestion is partly in line with Torkar [41], who measured students' attitudes towards forest ecosystem services. Here, the students had to assign different priorities to given ecosystem services. The students gave the lowest priority to cultural services, but in sharp contrast to our findings, the students ascribed the highest priority to supporting services. As our approach is different in that we used open-ended questions and did not measure attitudes as such, we suggest that the majority of our students do not recognize cultural and supporting services. Therefore, they seem to have a fragmented conception of the benefits of biodiversity for human welfare. Taking into consideration the more rural location and catchment areas of the sample schools, we would have expected students to express a greater appreciation for recreational values of natural environments. The schools involved are located in Bavaria, Germany within areas geographically characterized by contiguous forest and grassland ecosystems. We therefore presumed these ecosystems to be a relevant part of the participants' everyday life. Nevertheless, it was not within the scope of this study to compare rural and urban students. One possible reason for students not recognizing cultural services is that they simply have too little experience in nature because they prefer other types of leisure activities and can therefore not appreciate the aesthetic and recreational value of natural areas.

\subsection{Willingness to Protect Biodiversity}

The vast majority of students expressed willingness to protect biodiversity but only $60 \%$ gave reasons for their answer. The remaining $40 \%$ of students seem to have a positive attitude towards preservation but are not able to explain their opinion. Support for biodiversity protection was mostly justified by students expressing notions of environmental preservation. Notions of environmental utilization were less frequent. Only seven students recognized both the value of biodiversity for humans and its environmental value. For example, one student wrote (ID 42), 'Yes, because thereby we can protect species and the food and user chain remains.' All the other student answers indicated either ecocentric or anthropocentric values. Both views are united by the common goal to protect biodiversity but differ in their justification. The main reason why students want biodiversity to be protected for human welfare was the provision of ecosystem services. A frequent notion was that of ecosystems as producers, for example of oxygen or raw material, like wood. Those students who argued for biodiversity protection for environmental reasons, most frequently referred to the prevention of further species extinction. Again, media may drive formation of these conceptions, as it frequently covers endangerment of species.

\subsection{Educational Implications}

There are numerous studies concerned with challenges, guidelines, and approaches for biodiversity education [42-45]. Our findings contribute to the further development of biodiversity education strategies for formal and informal learning. Building an important element of ESD, the overarching goal of biodiversity education lies in enabling students to make informed decisions and be capable of acting in a pro-environmental manner. Pro-environmental behavior has been shown to be influenced and caused by various interdependent variables $[46,47]$. These include content knowledge, knowledge on related abilities and skills, motivational abilities such as attitudes, values and interest, feelings of self-efficacy but also socio-economic circumstances. For the present study, we decided to focus on 
content knowledge as a variable, which has already been shown to have an influence on adolescents' environmental behavior [48]. We understand conceptions of biodiversity as building an important prerequisite for understanding environmental interrelationships and for the development of positive attitudes towards the environment.

We suggest that every biodiversity education approach, first and foremost, needs to incorporate a scientific definition of biodiversity that includes all three levels of biodiversity. Defining biodiversity as species diversity is not completely wrong, but it is only half the story, and the whole concept is much more complex. Since species diversity seems to be widely known, more emphasis has to be placed on ecosystem and genetic diversity. Thereby, the complex topic offers the opportunity to connect several curricular contents concerning ecology, evolution and genetics. Students cannot easily understand the multidimensional concept of biodiversity. They need certain pre-knowledge in ecology and genetics. For example, they need to know the biological species concept, the definition of an ecosystem and interrelations within ecosystems, and they need basic knowledge in population genetics, e.g., genetic variation. In our specific case, genetics is a compulsory topic of the curriculum for the 9th grade of Bavarian secondary schools [49]. When teaching about biodiversity, educators should stimulate this existing knowledge to facilitate learning processes and cognitive structuring for learners.

Apart from the scientific definition of the concept, biodiversity education must include socio-scientific aspects. We agree with Torkar [41] that the topic of ecosystem services can serve to foster students' understanding as well as an appreciation of ecological structures, dependencies, and functions. Additionally, the socio-cultural context of ecosystem services encourages comprehension of the linkage between ecology and economy. We think that it is crucial for sustainable development that future generations understand and esteem nature's services, which contribute to human welfare. Our findings imply that it is important for educators to address all types of ecosystem services since supporting and cultural services were not present in the vast majority of the participants' conceptions. For an example of how to incorporate scientific as well as socio-scientific aspects of biodiversity within an educational module, please refer to Schneiderhan and Bogner [50]. We developed a module that used the forest ecosystem as an example to raise awareness of biodiversity protection and engaged students in a citizen science project to foster self-efficacy skills.

Biodiversity education approaches should also include outdoor experiences to foster students' appreciation of the cultural values of biodiversity. Research indicates that outdoor education potentially supports knowledge acquisition as well as environmental perceptions and estimations of nature [51-53].

Prior to planning a lesson, it is advisable for educators to deal with possible alternative conceptions of the learners. Literature provides valuable information concerning many different topics. Occasionally, however, it is worthwhile for teachers to capture conceptions of the respective students. Additionally, educators should make themselves aware of their own conceptions and potential alternative conceptions by doing detailed research and using recent literature when preparing a teaching subject.

Furthermore, our findings imply that biodiversity education needs to foster ecocentric attitudes. In our case, the majority of students already had ecocentric conceptions of the benefits of biodiversity, but $30 \%$ of the students argued for biodiversity protection from an anthropocentric point of view. Even if both anthropocentrism and ecocentrism suggest positive attitudes towards biodiversity protection, studies from Thompson and Barton [8] and Nordlund and Garvill [54] imply that ecocentric attitudes are more likely to be translated into eco-friendly behavior than anthropocentric values. Both studies found positive correlations between ecocentrism and pro-environmental behavior and negative or non-significant correlations between anthropocentrism and pro-environmental behavior. Additionally, Kibbe, Bogner and Kaiser [55] claim that, 'the more people appreciate nature for personal benefits, the more they preserve the environment'. We therefore conclude that it is important that students know and appreciate benefits of biodiversity for human welfare, but educational approaches should also stress biodiversity's environmental value and importance, to stimulate the willingness to protect biodiversity for environmental reasons and to contribute positively to the development of pro-environmental behaviors. 


\subsection{Outlook}

The method of using three-open ended questions represents a limitation of our study. We intentionally chose this approach to avoid any constraints or bias imposed by closed or multiple-choice questions as well as by interviews. If we had asked students about the value and protection of biodiversity in an interview, they would probably have been more inclined to answer according to what they regard as socially acceptable. This methodological challenge, known as social desirability bias (SDB) or socially desirable responding (SDR), has already been studied in environmental contexts [56,57]. Nevertheless, interviews would have allowed a deeper insight into the participants' conceptions by enabling posing of subsequent questions.

Additionally, recruiting school classes through convenience sampling does not allow generalized conclusions for an entire population [58]. Future research focusing on adolescents from various school types and social backgrounds would provide a deeper understanding and increased representativeness of our findings on adolescent conceptions of biodiversity.

Additionally, our study leaves open the question of whether student conceptions of the value and protection of biodiversity are consistent with their individual environmental value system. Is, for example, a student's human-centered concept of the benefits of biodiversity reflected in an overall anthropocentric view? A follow-up study needs to investigate that question by quantitatively monitoring the relevant values, applying the 2-MEV-model. This model conceptualizes the anthropocentric and ecocentric views of young individuals, and it has been repeatedly and independently confirmed by different angles of research [59-61]. Such a quantitative measure may cross-test the semi-quantitatively extracted conceptual preferences. Consequently, a follow-up study will deal with this issue.

Author Contributions: Conceptualization, J.S.-O.; data curation, J.S.-O.; formal analysis, J.S.-O.; funding acquisition, F.X.B.; investigation, J.S.-O.; methodology, J.S.-O. and F.X.B; project administration, F.X.B.; resources, F.X.B.; software, F.X.B.; supervision, F.X.B.; visualization, J.S.-O.; writing—original draft, J.S.-O.; writing一review and editing, F.X.B.

Funding: This research was funded by the 'Qualitätsoffensive Lehrerbildung' program of the German Federal Ministry of Education and Research (BMBF) under grant agreement no. 01JA160. The APC was funded by the German Research Foundation (DFG) and the University of Bayreuth in the funding program Open Access Publishing under grant agreement no. LA 2159/8-6. The funders had no role in the design of the study, in the collection, analyses, or interpretation of data, in the writing of the manuscript, or in the decision to publish the results. This article reflects only the authors' views. The BMBF and the DFG are not liable for any use that might be made of the information contained herein.

Acknowledgments: The authors would like to thank all participating students and their teachers for their time and effort.

Conflicts of Interest: The authors declare no conflicts of interest.

\section{References}

1. Duraiappah, A.K.; Naeem, S.; Agardy, T.; Ash, N.J.; Cooper, H.D.; Diaz, S.; Faith, D.P.; Mace, G.; McNeely, J.A.; Mooney, H.A.; et al. Ecosystems and Human Well-being: Biodiversity Synthesis; World Resources Institute: Washington, DC, USA, 2005.

2. Secretariat of the Convention on Biological Diversity (CBD). The Convention on Biological Diversity from Conception to Implementation. CBD News Special Edition. 2004. Available online: https://www.cbd.int/doc/ publications/CBD-10th-anniversary.pdf (accessed on 10 June 2019).

3. Secretariat of the Convention on Biological Diversity (CBD). List of Parties. Available online: https: //www.cbd.int/information/parties.shtml (accessed on 10 June 2019).

4. Butchart, S.H.M.; Walpole, M.; Collen, B.; van Strien, A.; Scharlemann, J.P.W. Global biodiversity: Indicators of recent declines. Science 2010, 328, 1164-1169. [CrossRef] [PubMed]

5. Secretariat of the Convention on Biological Diversity (CBD). Global Biodiversity Outlook 4; CBD: Montréal, CA, USA, 2014; ISBN 9292255401. 
6. Johnson, C.N.; Balmford, A.; Brook, B.W.; Buettel, J.C.; Galetti, M.; Guangchun, L.; Wilmshurst, J.M. Biodiversity losses and conservation responses in the Anthropocene. Science 2017, 356, 270-275. [CrossRef]

7. Hallmann, C.A.; Sorg, M.; Jongejans, E.; Siepel, H.; Hofland, N.; Sumser, H.; Ho, T.; Schwan, H.; Stenmans, W.; $\mathrm{Mu}, \mathrm{A}$.; et al. More than 75 percent decline over 27 years in total flying insect biomass in protected areas. PLoS ONE 2017, 12, e0185809. [CrossRef] [PubMed]

8. Thompson, S.C.G.; Barton, M.A. Ecocentric and anthropocentric attitudes toward the environment. J. Environ. Psychol. 1994, 14, 149-157. [CrossRef]

9. Washington, H.; Taylor, B.; Kopnina, H.; Cryer, P.; Piccolo, J.J. Why ecocentrism is the key pathway to sustainability. Ecol. Citiz. 2017, 1, 35-41.

10. Casas, A.B.; Burgess, R.A. The practical importance of philosophical inquiry for environmental professionals: A look at the intrinsic/instrumental value debate. Environ. Pract. J. Natl. Assoc. Environ. Prof. 2012, 14, 184-189. [CrossRef]

11. Tilman, D.; Isbell, F.; Cowles, J.M. Biodiversity and ecosystem functioning. Annu. Rev. Ecol. Evol. Syst. 2014, 45, 471-493. [CrossRef]

12. Mace, G.M.; Norris, K.; Fitter, A.H. Biodiversity and ecosystem services: A multilayered relationship. Trends Ecol. Evol. 2012, 27, 19-26. [CrossRef]

13. Alcamo, J. Ecosystems and their services. In Ecosystems and Human Well-being: A Framework for Assessment; Island Press: Washington, DC, USA, 2003; ISBN 1559634022.

14. Wood, A.; Stedman-Edwards, P.; Mang, J. The Root Causes of Biodiversity Loss; Routledge: London, UK, 2000; ISBN 9781138160194.

15. Grace, M. Teaching citizenship through science: socio-scientific issues as an important component of citizenship. Prospero 2006, 12, 42-53.

16. Ratcliffe, M.; Grace, M. Science Education for Citizenship: Teaching Socio-Scientific Issues; Open University Press: Maidenhead, UK, 2003; ISBN 0335210856.

17. Duit, R.; Treagust, D.F. Conceptual change: A powerful framework for improving science teaching and learning. Int. J. Sci. Educ. 2003, 25, 671-688. [CrossRef]

18. Treagust, D.F.; Duit, R. Conceptual change: A discussion of theoretical, methodological and practical challenges for science education. Cult. Stud. Sci. Educ. 2008, 3, 297-328. [CrossRef]

19. Helm, H. Misconceptions in physics amongst South African students. Phys. Educ. 1980, 15, 92-105. [CrossRef]

20. Abraham, J.K.; Perez, K.E.; Downey, N.; Herron, J.C.; Meir, E. Short lesson plan associated with increased acceptance of evolutionary theory and potential change in three alternate conceptions of macroevolution in undergraduate students. CBE Life Sci. Educ. 2012, 11, 152-164. [CrossRef] [PubMed]

21. Bishop, B.A.; Anderson, C.W. Student conceptions of natural selection and its role in evolution. J. Res. Sci. Teach. 1990, 27, 415-427. [CrossRef]

22. Maskiewicz, A.C.; Lineback, J.E. Misconceptions are “So Yesterday!". CBE Life Sci. Educ. 2013, 12, $352-356$. [CrossRef] [PubMed]

23. Piaget, J. La Construction du Réel Chez L'enfant; Delachaux et Niestlé: Neuchâtel, Switzerland, 1937; ISBN 2603007416.

24. Smith, J.P., III; DiSessa, A.A.; Roschelle, J. Misconceptions reconceived: A constructivist analysis of knowledge in transition. J. Learn. Sci. 1994, 3, 115-163. [CrossRef]

25. Lindemann-Matthies, P.; Bose, E. How many species are there? Public understanding and awareness of biodiversity in Switzerland. Hum. Ecol. 2008, 36, 731-742. [CrossRef]

26. Buijs, A.E.; Fischer, A.; Rink, D.; Young, J.C. Looking beyond superficial knowledge gaps: Understanding public representations of biodiversity. Int. J. Biodivers. Sci. Manag. 2008, 4, 65-80. [CrossRef]

27. Hunter, L.M.; Brehm, J. Qualitative insight into public knowledge of, and concern with, biodiversity. Hum. Ecol. 2003, 31, 309-320. [CrossRef]

28. European Comission. Special Eurobarometer 436-Attitudes of Europeans towards Biodiversity; European Comission: Bruxelles, Belgium, 2015. [CrossRef]

29. Fischer, A.; van der Wal, R. Invasive plant suppresses charismatic seabird-The construction of attitudes towards biodiversity management options. Biol. Conserv. 2007, 135, 256-267. [CrossRef]

30. Menzel, S.; Bögeholz, S. The loss of biodiversity as a challenge for sustainable development: How do pupils in chile and germany perceive resource dilemmas? Res. Sci. Educ. 2008, 39, 429-447. [CrossRef] 
31. Kilinc, A.; Yeşiltaş, N.K.; Kartal, T.; Demiral, Ü.; Eroğlu, B. School students' conceptions about biodiversity loss: Definitions, reasons, results and solutions. Res. Sci. Educ. 2013, 43, 2277-2307. [CrossRef]

32. Mayring, P. Qualitative Content Anaylsis. FQS 2000, 1, Art. 20. Available online: http://www.qualitativeresearch.net/index.php/fqs/article/view/1089/2385 (accessed on 10 March 2019).

33. Cohen, J. A coefficient of agreement of nominal scales. Educ. Psychol. Meas. 1960, 20, 37-46. [CrossRef]

34. Landis, J.R.; Koch, G.G. The measurement of observer agreement for categorical data. Biometrics 1977, 33, 159-174. [CrossRef]

35. Arbuthnott, K.D.; Devoe, D. Understanding of biodiversity among western Canadian university students. Hum. Ecol. 2014, 42, 147-158. [CrossRef]

36. Fischer, A.; Young, J.C. Understanding mental constructs of biodiversity: Implications for biodiversity management and conservation. Biol. Conserv. 2007, 136, 271-282. [CrossRef]

37. Schmid, S.; Bogner, F.X. Is there more than the sewage plant? University freshmen's conceptions of the urban water cycle. PLoS ONE 2018, 13, e0200928. [CrossRef] [PubMed]

38. Shaw, K.R.M.; van Horne, K.; Zhang, H.; Boughman, J. Essay contest reveals misconceptions of high school students in genetics content. Genetics 2008, 178, 1157-1168. [CrossRef] [PubMed]

39. Dekker, S.; Lee, N.C.; Howard-Jones, P.; Jolles, J. Neuromyths in education: Prevalence and predictors of misconceptions among teachers. Front. Psychol. 2012, 3, 429. [CrossRef] [PubMed]

40. Fiebelkorn, F.; Menzel, S. Student teachers' understanding of the terminology, distribution, and loss of biodiversity: Perspectives from a biodiversity hotspot and an industrialized country. Res. Sci. Educ. 2013, 43, 1593-1615. [CrossRef]

41. Torkar, G. Secondary school students' environmental concerns and attitudes toward forest ecosystem services: Implications for biodiversity education. Int. J. Environ. Sci. Educ. 2016, 11, 11019-11031.

42. Gayford, C. Biodiversity education: A teacher's perspective. Environ. Educ. Res. 2000, 6, 347-361. [CrossRef]

43. Van Weelie, D.; Wals, A. Making biodiversity meaningful through environmental education. Int. J. Sci. Educ. 2010, 24, 1143-1156. [CrossRef]

44. McCoy, M.W.; McCoy, K.A.; Levey, D.J. Teaching biodiversity to students in inner city \& under-resourced schools. Am. Biol. Teach. 2007, 69, 473-476. [CrossRef]

45. Navarro-Perez, M.; Tidball, K.G. Challenges of biodiversity education: A review of education strategies for biodiversity education. Int. Electron. J. Environ. Educ. 2012, 2, 13-30.

46. Stern, P.C. New environmental theories: Toward a coherent theory of environmentally significant behavior. J. Soc. Issues 2000, 56, 407-424. [CrossRef]

47. Chawla, L. Growing up green: Becoming an agent of care for the natural world. J. Dev. Process. 2009, 4, 6-23.

48. Roczen, N.; Kaiser, F.G.; Bogner, F.X.; Wilson, M. A competence model for environmental education. Environ. Behav. 2014, 46, 972-992. [CrossRef]

49. Staatsinstitut für Schulqualität und Bildungsforschung (ISB). Lehrplan für das Gymnasium G8 [Curriculum for Gymnasium G8]; ISB: Munich, Germany, 2007.

50. Schneiderhan, J.; Bogner, F.X. FutureForest-Promoting Biodiversity Literacy by Implementing Citizen Science in the Classroom. Am. Biol. Teach. 2019. accepted.

51. Bogner, F.X.; Wiseman, M. Outdoor ecology education and pupils' environmental perception in preservation and utilization. Sci. Educ. Int. 2004, 15, 27-48.

52. Benkowitz, D.; Köhler, K. Perception of biodiversity-The impact of school gardening. In Urban Biodiversity and Design; Müller, N., Werner, P., Kelcey, J.G., Eds.; Wiley-Blackwell: Chichester, UK, 2010; pp. 425-440. ISBN 9781444318654.

53. Lindemann-Matthies, P.; Junge, X.; Matthies, D. The influence of plant diversity on people's perception and aesthetic appreciation of grassland vegetation. Biol. Conserv. 2010, 143, 195-202. [CrossRef]

54. Nordlund, A.M.; Garvill, J. Value structures behind proenvironmental behavior. Environ. Behav. 2002, 34, 740-756. [CrossRef]

55. Kibbe, A.; Bogner, F.X.; Kaiser, F.G. Studies in educational evaluation exploitative vs. appreciative use of nature-Two interpretations of utilization and their relevance for environmental education. Stud. Educ. Eval. 2013, 41, 106-112. [CrossRef]

56. Ewert, A.; Galloway, G. Socially desirable responding in an environmental context: development of a domain specific scale. Environ. Educ. Res. 2009, 15, 55-70. [CrossRef] 
57. Oerke, B.; Bogner, F.X. Social desirability, environmental attitudes, and general ecological behaviour in children. Int. J. Sci. Educ. 2013, 35, 713-730. [CrossRef]

58. Etikan, I.; Musa, S.A.; Alkassim, R.S. Comparison of convenience sampling and purposive sampling. Am. J. Theor. Appl. Stat. 2016, 5, 1-4. [CrossRef]

59. Bogner, F.X.; Wiseman, M. Adolescents' attitudes towards nature and environment: Quantifying the 2-MEV model. Environmentalist 2006, 26, 247-254. [CrossRef]

60. Bogner, F.X.; Wiseman, M. Toward measuring adolescent environmental perception. Eur. Psychol. 1999, 4, 139-151. [CrossRef]

61. Milfont, T.L.; Duckitt, J. The structure of environmental attitudes: A first- and second-order confirmatory factor analysis. J. Environ. Psychol. 2004, 24, 289-303. [CrossRef]

(C) 2019 by the authors. Licensee MDPI, Basel, Switzerland. This article is an open access article distributed under the terms and conditions of the Creative Commons Attribution (CC BY) license (http://creativecommons.org/licenses/by/4.0/). 